\begin{tabular}{|ll}
\hline & $\begin{array}{l}\text { International Journal of Advanced Engineering, Management and Science } \\
\text { (IJAEMS) } \\
\text { ISSN: 2454-1311 } \\
\text { Vol-7, Issue-4; Apr, } 2021 \\
\text { JNFG GAIN }\end{array}$ \\
& $\begin{array}{l}\text { Journal Home Page Available: } \text { https://ijaems.com// } \\
\text { Journal DOI: } \text { https://dx.doi.org/10.22161/ijaems } \\
\text { Article DOI: } \text { https://dx.doi.org/10.22161/ijaems.74.2 }\end{array}$ \\
\hline
\end{tabular}

\title{
Factors Affecting Policyholders' Satisfaction towards Life Insurance: An Empirical Study on Life Insurance Policyholders in Bangladesh.
}

\author{
Sangita Basak
}

Lecturer, Dept. of Management Studies, Comilla University, Cumilla-3506 Bangladesh.

Received: 07 Jan 2021; Received in revised form: 01 Mar 2021; Accepted: 29 Mar 2021; Available online: 19 Apr 2021 (C2021 The Author(s). Published by Infogain Publication. This is an open access article under the CC BY license (https://creativecommons.org/licenses/by/4.0/).

\begin{abstract}
Insurance represents a very important tool to minimize risks borne by people and businesses in trendy economies. It's nothing but a mechanism of spreading the chance of one to the shoulders of the many. Insurance is one vital segments of monetary system. The insurance business is exclusive within the sense that it's rewarded for managing the chance of alternative parties. Human life is the most precious thing and life insurance is the most significant form of insurance that provides monetary protection to individuals and their families at the time of unsure risks or injury. Although life can't indemnify, life insurance provides a way of security, safety and protection to people and conjointly encourages savings among folks. This study aims to behold the factors affecting policyholders' satisfaction towards life insurance policies in Bangladesh which will help insurance companies to develop strategies to grow and sustain the life insurance business. The study is descriptive in nature, has been conducted supported both primary and secondary data. Twelve (12) variables have identified in this respect and hundred (100) policyholders are selected randomly from different locality. Collected data have tested with the help of various statistical tools like reliability and validity checking, regression analysis, ANOVA, weighted average method and hypothesis testing. The analyzed data has been presented in the form of table, graphs and charts. The study suggested that mass communication helps to form awareness and trust among the people with reference to taking associate degree contract strategy. The study concluded that low premium, service quality, efficient agent, trust, technology and communication are the most significant motivating factors compared to product feature, price, flexibility, brand value, economic growth and maturity benefits on policyholders`satisfaction. This study can become useful for the advance of insurance in Bangladesh.
\end{abstract}

Keywords-Bangladesh, Life-insurance, Policyholders`satisfaction, Service quality, Trust.

\section{INTRODUCTION}

Insurance could be a contract, diagrammatical by a policy, within which a private or entity receives monetary protection or compensation against losses from associate degree no depository financial institution. Insurance is a very important risk mitigation device. It provides a way of security. Insurance works on the principle of pooling of risks and distributes risks over many folks. Insurance is a useful aid to trade. Insurance is one vital segments of monetary system. The insurance business is exclusive within the sense that it's rewarded for managing the chance of alternative parties.

Insurance sector in Bangladesh emerged after independence with 2 nationalized insurance companies- 1 Life \& 1 General; and 1 foreign insurance company. In mid 80s, private sector insurance companies started to enter in the industry and it got expanded. Now days, 62 companies are operating under Insurance Act 2010. Out of them- 18 are Life Insurance Companies including 1 foreign company and 1 is state-owned company, 44 
General Insurance Companies including 1 state-owned company. Insurance companies in Bangladesh provide following services: Life insurance, General Insurance, Reinsurance, Micro-insurance, and Takaful or Islami insurance.

Although Bangladesh's insurance sector has witnessed some growth, as compared with alternative rising nations, there's loads of area for improvement. According to the Seventh Five Year Plan (2016-2020) of the Government of Bangladesh, a majority of the population across product segments (life and non-life) remains untapped by the insurance market. In 2019, overall insurance penetration in the country is approximately 0.57 per cent compared to Thailand's average of 5.27 per cent, Malaysia's 4.77 per cent, China's 4.22 per cent, India's 3.7 per cent, Indonesia's 1.95 per cent and Sri Lanka's 1.15 per cent. This indicates that rising Asia Pacific economies area unit investing the advantages of insurance for growth and development. There are 78 insurance companies - 32 life and 46 non-life - operating in the country at present. In 2018, Bangladesh's payment earnings rose by eleven.06 per cent to Tk 124.165 billion, in keeping with information obtainable with the Insurance Development and administrative unit (IDRA). The gross premium from life insurances stood at Tk 90.20 billion in the year, up by 10.10 per cent while premium of non-life insurance stood at Tk 33.97 billion showing 13.92 per cent rise. Life insurers disbursed a total claim payment of Tk 65.71 billion with the claim settlement ratio of 88.51 per cent.

However, with the recent increase in life expectancy, around 20 per cent of the population will be older people (65 years and beyond). From an economic perspective, a growing senior population will mean reallocating economic and other resources. Bangladesh is yet to establish a sustainable social security program for the elderly people. Except for the government service-holders and few other social safety net programs, the country does not have massive coverage of social security services. In this context, insurance is such an industry that has the capability of complementing the government programs for ensuring sustainable development.

\section{OBJECTIVES OF THE STUDY}

The main purpose of this research is to explore the policyholders`satisfaction level regarding life insurance which will help insurance companies to develop strategies to grow and sustain in the life insurance business. Some other objectives are-

i. to find out the impact of service quality on policyholders' satisfaction. ii. to find out the influence of insurance agents on policyholders' satisfaction

iii. to find out the impact of communication on policyholders' satisfaction

iv. to find out the impact of brand value on policyholders' satisfaction

v. to find out the impact of maturity benefits on policyholders' satisfaction

\section{RESEARCH HYPOTHESIS}

H01. There is no impact of Service Quality on policyholder`s satisfaction

H02. There is no impact of Insurance Agents on policyholder's satisfaction

H03. There is no impact of Communication on policyholder's satisfaction

H04. There is no impact of Brand Value on policyholder's satisfaction

H05. There is no impact of Maturity Benefits on policyholder`s satisfaction

\section{REVIEW OF LITERATURE}

Customers were the main pillars of any business and customer service is the critical success factor in a company and providing outstanding customer service differentiates great customer service from indifferent customer service. Customers today are more demanding and expecting high standards of service and value satisfaction. If all the players in the life insurance industry focus on the effective delivery of services they could win the hearts of customers and anticipate their increased market share. Customer service assumes vital importance in the marketing programs of all modern organizations including service organizations. Insurance companies need to improve its service quality to meet changing demands and expectations of customers. (Yadav., 2011) Customer satisfaction determinants such as (a) operational efficiency, (b) quality service delivery, (c) technological infrastructure, and (d) customer appreciation of insurance offerings may translate into life insurance business growth in Ghana (Akotey \& Adjasi, 2015; Alhassan \& Fiador, 2014). Frank and Enkawa examined the impact of economic growth and economic expectation that influence the customer satisfaction and their quality. They found that policyholders are positively influenced towards economic growth and negatively influenced towards their economic expectation and also found that economic expectation and quality expectations are positively correlated. (Frank \& Enkawa, 2009). An article titled, "Policyholders Satisfaction with the Agency-Based Sales Surpasses Satisfaction with Direct Sales in Japan", reveals that 
policyholders are more satisfied with timely services, procedure and documentation followed, low premium and innovative products offered by the Prudential Life Insurance Company. (J, 2011). in their article Anshuja Tiwari and Babita Yadav reveal that prompt customer service, after-sales services, innovative products with flexibility and better communication influences the customer satisfaction towards private life insurers than public sector insurer, LIC. (Tiwari \& Yadav, 2012). Deepika Upadhyaya and Manish Badlani carried out a study entitled, "Service Quality Perception and Customer Satisfaction in Life Insurance Companies in India", with a view to identify customer satisfaction in retail life insurance in India. They identify that the policyholders are more satisfied with the pricing factor followed by employee competence, product and service, technology, physical ambience of the company, trust, service delivery, advertising and service management. (Upadhyaya \& Badlani, 2011). Policyholders are more satisfied with the policy features, price, maturity benefits and tax saving contents. (Negi \& Kaur, 2010). Policyholders are highly satisfied with the premium amount fixed by the company and the maturity amount received after the maturity period. (Panchanatham, Jhansi, Kumar, \& Mani, 2008) Paromita Goswami carried out a study to identify the dimensions of service quality that ensures maximum satisfaction for the customers in the life insurance industry. She finds that customers are more satisfied with responsiveness dimension of service quality namely, promptness and timeliness in service as well as willingness to help the customers. The insurance companies have to work and concentrate on time-based competition, quality, product range, timely advertisement, follow up, prompt and errorfree services which are the key ingredients for the better service and it will boost up the sales. (Goswami, 2007). Upadhyaya (2011) finds out the factors of customer satisfaction in life insurance and study the importance technology in full fling customer satisfaction. Study highlights the role of technology to improve quality and customer satisfaction. Researcher finding the majority of policyholders who are strongly recognizable with interpersonal services may never be satisfied with technology-based service. Siddiqui and Sharma investigate service quality framework for life insurance and then relative importance of these service quality dimensions from customer's viewpoint. The paper attempt to measure as to how well services are being delivered i.e., up-to what level performances are meeting the expectations. The result tinted the main concern areas of service instrument with assurance is the best interpreter, followed by competence and personalized financial planning. The insurance companies have to work and concentrate on time-based competition, quality, product range, timely advertisement, follow up, prompt and error-free services which are the key ingredients for the better service and it will boost up the sales. (Siddiqui \& Sharma, 2010). Policyholders of life insurance policies seek personalized services and constant support in financial planning e.g., flexible payment schedule, flexible product solution, provisions for convertibility of products and supplementary services etc. So, service providers should encourage the agents to assume wider roles, that of financial consultants. (Subashini \& Velmurugan, 2016). In his study (sinha, 2013) stated that insurance companies are working in a highly competitive market where consumers have many companies and products to choose from. Hence it becomes necessary for insurance companies to maintain loyal customer base by increasing customer loyalty through improved service quality. His study given by factor analysis is performed where five factors are derived namely, sincere and prompt services, comparison and courteous, meticulous and customers orientation, flexibility and tangibility. The study emphasizes that the customers should be given prompt service. They should feel safe in their dealings with the company and the company should give individual attention to the customer. Manuel conducted the study to understand the Consumer Perception about life insurance policies. The survey was conducted to find out the attributes which affect decision making of consumers of life insurance policies which are return on investment, company reputation, premium outflow, service quality and product quality (Manuel, 2013). Yadav and Tiwari find out factors influencing customer investment decision, impact of various demographic factors, preferences of customers while taking the decision, and ranking of factors responsible for the selection life insurance as an investment option. The features that policyholders consider while making a purchase can be ranked as follows: company reputation, money back guarantee, risk coverage, low premium and easy access to agents as 1st, 2nd, 3rd, 4th and 5th respectively. Thus, it could be concluded that goodwill of the company is the most influencing factor while policy buying decision. It was found that majority of respondents preferred money back policy. (Tiwari \& Yadav, 2012). Kaur and Negi conducted their study in Chandigarh and by using factor analysis they found customized and timely service, brand value, considerate employee, price immunity as major factors affecting the satisfaction of customers. They even found that maximum life covered under insurance are of male than female and satisfaction level among public and private sector insurance companies is same. (Negi \& Kaur, 2010). M. Epctimchin (2011); conducted a survey in Nigeria to find out factors 
enhancing the purchasing of life insurance and found that company loyalty is the major factor influencing purchasing decision and company client relationship as the last. These factors are beneficial to company as well as consumer. Sandhu and Bala found 7 factors composed of proficiency, media and presentations, physical and ethical excellence, service delivery process and purpose, security and dynamic operation, credibility and functionality. Along with these factors' managerial implication like performance of agents also affect customer satisfaction $(\mathrm{H}$ \& N, 2010). A study on "Determinants of customer Satisfaction: A Model of Technology Integration in Thailand's Insurance Industry" depicts that magnitude of technology integration directly influences customer satisfaction whereas technology readiness of salespeople and customer indirectly influences the customer satisfaction towards insurance provider. (Larpsiri \& Speece, 2004). In his survey entitled, "Insurers Score Low in Client Satisfaction", (Hongmei, 2016) observes that the policyholders are dissatisfied with the insurer's services with regard to customer complaint lodged and claim settlement. The hostility of this study is to assay the brunt of demographic factors on the extent of satiation of investor's contra insurance policies. The study entraps the impact of demographics factors on the satisfaction of investors towards insurance policies. This paper conjointly evaluates cogent relationship between demographic factors and overall satisfaction of the shoppers towards the insurance policies. (Sharma, Sai, Vijay, P., \& Sharma, 2012)

\section{ANALYSIS AND INTERPRETATION 6.1 Demographic Analysis}

The demographic analysis of the respondent represent that the majority of the respondents are of the age

\section{METHODOLOGY OF THE STUDY}

Research methodology is the specific procedures or techniques used to identify, select, process, and analyze information about a topic. In a research paper, the methodology section allows the reader to critically evaluate a study's overall validity and reliability (David Wilkinson, 2020). The current research is a descriptive research. This research study has been conducted among the life insurance policy holders from different public and private insurance companies in different urban and rural areas in Bangladesh based on random sampling in which 100 policyholders (male and female) have been selected as sample. This study is based on both primary and secondary data. For Primary data collection, pertinent information have been gathered by surveying among the policyholders. Both questionnaire and interview secessions have been conducted to gather primary data. All of the items in the questionnaire have been measured on 5-point Likert scale (1= strongly disagree, $2=$ disagree, $3=$ neutral, $4=$ agree and $5=$ strongly agree). Interview secession has been conducted on 30 respondents from different private and public insurance companies in Bangladesh. For secondary research, relevant literature from books, articles, newspapers, and magazines have been collected Descriptive statistics is used for analyzing data including Reliability, multiple Regression analysis, ANOVA and Hypothesis test in SPSS 20 version.

between 45-54 years, most of them are male respondent and they are married, their educational level is graduation and majority of them are government job holders.

Table-1: Demographic information of the respondents

\begin{tabular}{|l|l|l|l|l|l|}
\hline & $\begin{array}{l}\text { Age of the } \\
\text { respondent }\end{array}$ & $\begin{array}{l}\text { Marital } \\
\text { Status }\end{array}$ & $\begin{array}{l}\text { Educational } \\
\text { Qualification }\end{array}$ & $\begin{array}{l}\text { Gender of the } \\
\text { Respondent }\end{array}$ & $\begin{array}{l}\text { Source of } \\
\text { Earnings }\end{array}$ \\
\hline N Valid & 100 & 100 & 100 & 100 & 100 \\
Mean & 0 & 0 & 0 & 0 & 0 \\
Std. Error of Mean & .102 & .031 & .114 & .049 & 3.29 \\
Std. Deviation & 1.016 & .314 & 1.143 & .485 & 1.27 \\
Variance & 1.032 & .099 & 1.305 & .235 & 1.622 \\
Range & 3 & 1 & 4 & 1 & 4 \\
\hline
\end{tabular}




\subsection{Reliability and Validity of data}

Reliability refers to the consistency of set of items in measuring the study variables (Cooper \& Schinder, 2001). Cronbach's alpha is commonly used method to measure the reliability or internal consistency that is, how closely related a set of items are as a group (Cooper \& Schinder,
2001). The satisfactory value in Cronbach's alpha is required to be more than 0.60 to be reliable (Malhotra, 2002). In this study, Cronbach's alpha is .786 (Table-2), which indicates a satisfactory level of internal consistency for the scale.

Table-2 Reliability Statistics

\begin{tabular}{|l|l|l|}
\hline Cronbach's Alpha & $\begin{array}{l}\text { Cronbach's Alpha Based on } \\
\text { Standardized Items }\end{array}$ & N of Items \\
\hline .786 & .715 & 12 \\
\hline
\end{tabular}

\subsection{Regression Analysis}

\subsubsection{Model Summary}

The value of $\mathrm{R}$ Square $(0.741)$ and $\mathrm{R}(0.835)$ shows that there is strong association between the set of independent variables and the dependent variable with the standard error of 0.410 (Table-4) .In additions, the Table- 3 implies that the policyholder`s satisfaction towards life insurance policies in Bangladesh is $74 \%$ dependent on service quality, product features, pricing factors, flexibility, trust, agents, communication, uses of technology, premium, brand value, economic growth and maturity benefits. The rest $26 \%$ is dependent on some others factors that are not considered by the researcher in this study.

Table-3 Regression Model Summary

\begin{tabular}{|l|l|l|l|l|}
\hline \multirow{2}{*}{ Model } & & & & \\
& $\mathrm{R}$ & R Square & Adjusted R Square & $\begin{array}{l}\text { Std. Error of the } \\
\text { Estimate }\end{array}$ \\
\hline 1 & $.835^{\mathrm{a}}$ & .741 & .778 & .410 \\
\hline
\end{tabular}

Source: SPSS output.

\subsection{ANOVA test}

The $\mathrm{F}$ value of the test for the data is 38.542 . The p-value associated with this $\mathrm{F}$ value which is .000 which is lower than the alpha value 0.05 (Table-4). In additions, The
Table-4 implies that there is significant influence of these independent variables on the dependent variable and the model applied is significantly good to predict the dependent variable.

Table-4 ANOVA ${ }^{b}$

\begin{tabular}{|ll|l|l|l|l|l|}
\hline Model & & Sum of Squares & Df & Mean Square & F & Sig. \\
\hline 1 & Regression & 84.872 & 12 & 7.073 & 38.542 & $.000^{\mathrm{a}}$ \\
& Residual & 72.038 & 88 & .328 & & \\
& Total & 156.910 & 100 & & & \\
\end{tabular}

a. Predictors: (Constant), Service Quality(V1), Product Feature(V2), Pricing Factor(V3), Flexibility(V4), Trust(V5), Agent(V6), Communication(V7), Technology(V8), Low Premium(V9), Brand Value(V10), Economic Growth(V11), Maturity Benefit(V12)

b. Dependent Variable: Policyholder`s Satisfaction 


\subsection{Regression Coefficients}

In Table 5, Since the beta values are the standardized versions of the b-values and are directly comparable, these values may be used to infer regarding the relative importance of each predictor or independent variables to the model. In other words, the beta coefficients could be used to explain the relative importance of the 8 dimensions or factors (V1 to V12 i.e., independent variables) in contributing to the variance in the factors affecting policyholder's satisfaction towards life insurance policies in Bangladesh.

The application of the beta-values in the multiple regression model equation $(\mathrm{YCCT}=\beta 0+\beta 1 \mathrm{v} 1+\beta 2 \mathrm{v} 2+$ $\beta 3 \mathrm{v} 3+\beta 4 \mathrm{v} 4+\beta 4 \mathrm{v} 5+\beta 4 \mathrm{v} 6+\beta 4 \mathrm{v} 7+\beta 4 \mathrm{v} 8+\beta 4 \mathrm{v} 9+$ $\beta 4 \mathrm{v} 10+\beta 4 \mathrm{v} 11+\beta 4 \mathrm{v} 12 \mathrm{Or},=.299+.837+.502+.437+$ $.464+.738+.780+.634+.715+.888+.445+.344+$ $.362)$ interprets this model to mean that for every increase of one unit in $\mathrm{v} 1$, assuming the effects of $\mathrm{v} 2$ to $\mathrm{v} 12$ be held constant, factors affecting policyholder`s satisfaction towards life insurance policies in Bangladesh would increase by 0.540 . Likewise, should the effects of other components be held constant, a single unit increase in v2 would result in a 0.410 increase in factors affecting policyholder`s satisfaction towards life insurance policies in Bangladesh. Similarly, being other components held constant a single unit increase in v3 to v12 would lead to a $.346, .476, .525, .554, .476, .562, .576, .226, .218$ and .260 increase respectively in the factors affecting policyholder's satisfaction towards life insurance policies in Bangladesh.

Table-5 Coefficients

\begin{tabular}{|ll|l|l|l|l|l|}
\hline \multirow{2}{*}{ Model } & & \multicolumn{2}{|l|}{ Unstandardized Coefficients } & \multicolumn{2}{l|}{$\begin{array}{l}\text { Standardized } \\
\text { Coefficients }\end{array}$} & \\
\cline { 2 - 6 } & & B & Std. Error & Beta & T & Sig. \\
\hline 1 & (Constant) & .299 & .198 & & .819 & .415 \\
& Service quality (V1) & .837 & .085 & .540 & 8.433 & .006 \\
& Product feature (V2) & .502 & .102 & .410 & 2.008 & .016 \\
Pricing factor (V3) & .437 & .147 & .346 & 2.982 & .004 \\
Flexibility (V4) & .464 & .138 & .476 & 3.374 & .001 \\
Trust (V5) & .738 & .140 & .525 & 2.270 & .028 \\
Agent (V6) & .780 & .153 & .554 & 3.521 & .003 \\
Communication (V7) & .634 & .157 & .476 & 4.030 & .000 \\
Technology (V8) & .715 & .169 & .562 & 4.234 & .000 \\
Low Premium (V9) & .888 & .157 & .576 & 10.562 & .026 \\
Brand value (V10) & .445 & .231 & .226 & 2.926 & .047 \\
Economic growth (V11) & .344 & .181 & .218 & 2.904 & .030 \\
Maturity benefit (V12) & .362 & .129 & .260 & 2.477 & .034 \\
\hline
\end{tabular}

a. Dependent Variable: DV

Since there are more than one predictors (independent variables), the magnitude of the t-value in conjunction with the significance has been considered to assess the overall contribution to the model. Based on the decision rule "the greater the $\mathrm{t}$-value, the greater the contribution of the predictor", it is seen that $v 9$ : $(\mathrm{t}=10.562)$ followed by v1: $(\mathrm{t}=8.433), \mathrm{v} 8:(\mathrm{t}=4.234), \mathrm{v} 7:(\mathrm{t}=4.030), \mathrm{v} 6:(\mathrm{t}=3.521)$, v4: $\quad(t=3.374), \quad v 3: \quad(t=2.982), \quad v 10: \quad(t=2.926), \quad v 11:$ $(\mathrm{t}=2.904), \quad \mathrm{v} 12: \quad(\mathrm{t}=2.477), \quad \mathrm{v} 5: \quad(\mathrm{t}=2.270), \quad$ and $\quad \mathrm{v} 2$ : $(\mathrm{t}=2.008), \quad$ are all significant predictors or independent variables of the factors affecting policyholder's satisfaction towards life insurance policies in Bangladesh. 
In this regard, from the t-values it can be also concluded that $\mathrm{v} 9$ has a greater impact on the outcome than $\mathrm{v} 1, \mathrm{v} 8$, v7, v6, v4, v3, v10, v11, v12, v5, and v2.

In summary, it can be stated that all underlying dimensions are positive and therefore are significant. Thus, the result of multiple regression analysis rejects all of the null hypothesis (H01-H05) and proves or accepts the alternative hypothesis (Ha1-Ha5). So, there is a relationship as expected.

So, the regression model achieved a satisfactory level of goodness-of-fit in predicting the variance of policyholder's satisfaction in relation to the 12 predictors or independent variables, as measured by the above-mentioned R, R2, Adjusted R2, F ratio, beta and $t$ values. In other words, at least one of the 12 predictors or independent variables of the model is important in affecting the policyholder's satisfaction towards life insurance policies in Bangladesh.

\section{FINDINGS AND RECOMMENDATIONS}

The findings of the study reviles that some independent variables have greater impact on policyholder's satisfaction compared to other variables. When prospective policyholders decide to choose a particular policy from a particular insurance company, they appreciate low premium, services quality of the company, insurance agents, trust on the company and use of technology in service delivery system. There are some other factors like communication between company and client before and after the policy purchase, product features, flexibility in payment and documentation system, brand value of the company in the market, product pricing, and maturity benefit received after the policy maturity and economic growth form the policy. From the demographic analysis it is clear that most of the policyholders are male and they are from the age group of 45-54 years. Although now-adays female have a greater participation in economic activities but there is a smaller number of female policyholders compared to male policyholder. From the above findings it can be recommended that amount and number of premium need to be carefully set, service quality need to be maintained, companies should recruit qualified and efficient agents so that they can rise trust among the people. Technology is a useful tool to communicate with the prospective and existing customers as companies can easily inform about the updates regarding product, price and it can also be used as a promotional tool. Companies should focus on their brand values as a strong brand value increases trust among customers. Overall, insurance companies need to be developed proper and competitive strategies to attract more and more customers and to sustain in the competitive market.

\section{CONCLUSION}

This is the law of nature that human have to be compelled to live and play with hazards and to some extent insurance will free from those frustrations. Insurance firms play a very important role within the welfare of. human wellbeing by providing protection to uncountable folks against life risks like unsure death or accident Customers have specific opinions on their purchase or consumption expertise from a product or service. A growing life insurance industry that complements a country's sustainable economic development strategy creates the financial support to manage the risk of dying early or living too long (Blake, Cairns, Coughlan, Dowd, \& MacMinn, 2013; Smith, 2014 ). Life insurance practitioners need to identify strategies to enhance the life insurance pool and support the sustainability of the business (Kramaric \& Galetic, 2013). These strategies might aid insurance practitioners to develop appropriate insurance products and services accessible to the uninsured population in Bangladesh.

\section{ACKNOWLEDGMENTS}

I thank the previous authors for their contributions in this field of study. I also thank all those women who have spent their valuable time in the questionnaire survey informal interview sessions. There is no conflict of interest in the publication of this manuscript.

\section{REFERENCES}

[1] B. Yadav., "Customer satisfaction on life insurance services: An empirical study on LIC.," International Journal of Marketing and Management Research, vol. 2, no. 2, pp. 150-156, 2011.

[2] B. Frank and T. Enkawa, "Economic Influences on Perceived Value, Quality Expectations, and Customer Satisfaction," International Journal of Consumer Studies, vol. 331, pp. 72-82, 2009.

[3] P. J, "Policyholders Satisfaction with the Agency-Based Sales Surpasses Satisfaction with Direct Sales in Japan.," Insurance Regulatory and Developement Authority Journal, vol. 8, pp. 8-12, 2011.

[4] A. Tiwari and B. Yadav, "A Customer Survey \& Perception towards Bancassurance (With Reference to Life Insurance Industry).," South Asian Journal of Marketing \& Management Research, vol. 2, no. 2, p. 142-164, 2012.

[5] D. Upadhyaya and M. Badlani, "Service Quality Perception and Customer Satisfaction in Life Insurance Companies in 
India," IRDA Journal, vol. 2, pp. 23-31, 2011.

[6] M. Negi and D. P. Kaur, "A study of customer satisfaction with life insurance in Chandigarh tricity. Paradigm," SAGE Journals, vol. 14, no. 2, pp. 29-44, 1 July 2010.

[7] N. Panchanatham, S. Jhansi, S. Kumar and A. Mani, "A Study on Policy Holder's Expectation and Preference towards Selected Private Life Insurance Companies in Karur District,," Indian Journal of Marketing,, vol. 38, no. 8, August 2008.

[8] P. Goswami, "Customer Satisfaction with Service Quality in the Life Insurance Industry in India," The IUP Journal of Sevices Marketing, vol. V, no. I, 2007.

[9] M. Siddiqui and T. G. Sharma, "Analyzing customer satisfaction with service quality in life insurance services," Journal of Targeting Measurement and Analysis for Marketing, vol. 18, no. 3, 2010.

[10] S. Subashini and D. R. Velmurugan, "Policyholders Satisfaction of Life Insurance Products with Reference to Coimbatore District," International Journal of Business and Management Invention, vol. V, no. 4, pp. 28-38, April 2016.

[11] K. sinha, "Measurement of Service Quality: A Life Insurance Industry Perspective," Journal of Marketing Vistas, vol. III, no. 1, pp. 54-66, 2013.

[12] J. Manuel, "The long road to recovery: environmental health impacts of Hurricane Sandy. Environ Health Perspect," National Center for Biotechnology Information, 2013.

[13] S. H and B. N, "Customers' Perception towards Service Quality of Life Insurance Corporation of India: A Factor Analytic Approach," International Journal of Business and Social Science, vol. II, no. 18, pp. 219- 231, 2010.

[14] R. Larpsiri and M. Speece, "Determinants of customer Satisfaction: A Model of Technology Integration in Thailand's Insurance Industry," IRDA Journal, vol. 7, pp. 18-21, 2004.

[15] S. Hongmei, "Insurers Score Low in Client Satisfaction," IRDA Journal, no. 10, pp. 22-26, 2016.

[16] M. Sharma, T. Sai, Vijay, P. L. P. and S. Sharma, "Impact of Demographic Factors on the Satisfaction of Investors towards Insurance Policies: An Empirical Study," IJRFM (International Journal of Research in Finance \& Marketing), vol. 2, no. 1, pp. 54-67, 2012. 